\title{
Effect of modified atmosphere on polyphenols during storage of pasteurised strawberry purées
}

\author{
Ana Oliveira a , Elisabete M.C. Alexandre a, Marta Coelho a, Maria Helena Gomes c, \\ Domingos P.F. Almeida ${ }^{\text {b }}$, Manuela Pintado ${ }^{\text {a, * }}$, \\ ${ }^{a}$ Centro de Biotecnologia e Química Fina - Laboratório Associado, Escola Superior de Biotecnologia, Universidade Católica Portuguesa/Porto, \\ Rua Dr. António Bernardino Almeida, 4200-072 Porto, Portugal \\ ${ }^{\mathrm{b}}$ Instituto Superior de Agronomia, Universidade de Lisboa, Tapada da Ajuda, 1349-017 Lisboa, Portugal \\ ${ }^{\mathrm{c}}$ Frulact, S.A., Rua do Outeiro, 589, 4475-150 Gemunde, Maia, Portugal
}

\section{A R T I C L E I N F O}

\section{Article history:}

Received 4 February 2014

Received in revised form

10 September 2014

Accepted 11 September 2014

Available online 22 September 2014

\section{Keywords:}

Anthocyanins

Fragaria $\times$ ananassa Duch.

Modified atmosphere packaging

Processing

\begin{abstract}
A B S T R A C T
The minimum loss of processed fruit nutritional quality must been guaranteed during storage and the atmosphere can be a limiting step.

Strawberry purées flushed with gas mixtures: $10 \mathrm{kPa} \mathrm{O}_{2}+90 \mathrm{kPa} \mathrm{N}, 100 \mathrm{kPa} \mathrm{N}$ and air $(78 \mathrm{kPa}$ $\mathrm{N}_{2}+21 \mathrm{kPa} \mathrm{O} \mathrm{O}_{2}+0.03 \mathrm{kPa} \mathrm{CO}$ ) were stored for 90 days at 4 and $23{ }^{\circ} \mathrm{C}$ and revealed no effect in total antioxidant activity and in total phenolic content. The compounds (+)-catechin, (-)-epicatechin and quercetin-3-rutinoside were not affected by the atmospheres for both temperatures and ellagic acid was the exception within strawberry phytochemicals, where its concentration was higher for samples stored in air.

Total anthocyanin content was better preserved when strawberry purée was stored in $100 \mathrm{kPa} \mathrm{N}_{2}$ at 4 and $23{ }^{\circ} \mathrm{C}$, at which temperatures their levels decreased 24 and $77 \%$, respectively. At $4{ }^{\circ} \mathrm{C}$ cyanidin-3glucoside presented no significant differences between atmospheres. Pelargonidin-3-glucoside and pelargonidin-3-rutinoside decreased both $27 \%$ for $100 \mathrm{kPa} \mathrm{N} 2$ and $45 \%$ for $10 \mathrm{kPa} \mathrm{O}_{2}$ and air. All the individual anthocyanins were not affected by the atmospheres when stored at $23^{\circ} \mathrm{C}$.
\end{abstract}

๑) 2014 Elsevier Ltd. All rights reserved.

\section{Introduction}

Modified atmosphere has been used as a way to better control undesirable changes promoted by oxidative reactions. Modified atmosphere can be defined as one that is created by altering the normal composition of air ( $78 \mathrm{kPa}$ nitrogen, $21 \mathrm{kPa}$ oxygen, $0.03 \mathrm{kPa}$ carbon dioxide and traces of noble gases) to provide an adequate, although not strictly controlled, atmosphere for increasing the storage period and quality of food (Farber et al., 2003).

Industrially processed fruit are subjected to different unit operations that can affect their structure, favouring the occurrence of chemical reactions (Aguilar-Rosas, Ballinas-Casarrubias, NevarezMoorillon, Martin-Belloso, \& Ortega-Rivas, 2007; García-Torres, Ponagandla, Rouseff, Goodrich-Schneider, \& Reyes-De-Corcuera, 2009). During these procedures cells compartmentation is lost, cell walls disrupted and air is incorporated into the purées.

\footnotetext{
* Corresponding author. Tel.: +351 225580097.

E-mail address: mpintado@porto.ucp.pt (M. Pintado).
}

Metabolites and enzymes that are compartmentalized are mixed, producing chemical and biochemical reactions, some of them promoted by oxygen present in air leading to oxidation reactions that often result in browning, changes in aroma, and loss of nutritional value (García-Torres et al., 2009).

The nutritional quality of strawberry is related primarily to their richness in polyphenols (Klopotek, Otto, \& Bohm, 2005). Diversity and content of polyphenols in processed strawberry may decrease during storage, depending on conditions such as time, temperature and oxygen content (Alwazeer, Delbeau, Divies, \& Cachon, 2003; Ioannou, Hafsa, Hamdi, Charbonnel, \& Ghoul, 2012; Kalt, McDonald, \& Donner, 2000).

Studies concerning adverse effects of dissolved oxygen on the quality attributes of fruit juices have been reported by many researchers including studies about ascorbic acid degradation by oxidation reactions (Aguilar-Rosas et al., 2007; Solomon, Svanberg, \& Sahlström, 1995; Zerdin, Rooney, \& Vermuë, 2003).

In fruit processing, usually modification of an atmosphere involves a reduction of oxygen or an increase of carbon dioxide or nitrogen concentrations. The lower content oxygen has reported to 
slow down spoilage microorganisms and nitrogen is used to displace oxygen in order to retard aerobic spoilage and oxidative deterioration (Erkmen, 2012).

The atmospheres choice for this study was dependent on prevention of oxidative deterioration. Air was used as control, $100 \mathrm{kPa}$ $\mathrm{N}_{2}$ was selected to represent the total absence of oxygen and a mild $\mathrm{O}_{2}$ concentration of $10 \mathrm{kPa}$ was selected. To minimize fruit nutritional quality losses, the atmosphere along storage must be controlled beyond processing. Given the lack of information about chemical changes occurring in fruit after processing, this study gives an additional survey to the established information.

The main purpose of this work was to evaluate phytochemicals concentration during 90 days-storage of pasteurised strawberry purée under three atmospheres (air, $100 \mathrm{kPa} \mathrm{N} \mathrm{N}_{2}$ and $10 \mathrm{kPa}$ $\mathrm{O}_{2}+90 \mathrm{kPa} \mathrm{N}$ ) and at two storage temperatures (4 and $23^{\circ} \mathrm{C}$ ) for future recommendations to improve polyphenols preservation of fruit processed.

\section{Materials and methods}

\subsection{Chemicals}

Methanol, formic acid (Sigma-Aldrich, Sintra, Portugal) and hydrochloric acid (Merck, Oeiras, Portugal) were all of HPLC grade. Reagents used for determinations of total phenolic compounds, antioxidant activity and total anthocyanins were 2, 2-azinobis-3ethylbenzothiazoline-6-sulphonic acid (ABTS), potassium chloride, potassium sorbate, sodium carbonate, sodium acetate (Sigma-Aldrich, Sintra, Portugal), Folin-Ciocalteu's reagent and potassium persulfate (Merck, Oeiras, Portugal). Standards used for calibration curves were ascorbic acid, gallic acid, (+)-catechin, (-)-epicatechin, ellagic acid, quercetin-3-rutinoside (Sigma-Aldrich, Sintra, Portugal), cyanidin-3-glucoside, pelargonidin-3-glucoside and pelargonidin-3rutinoside (Extrasynthése, Lyon, France).

\subsection{Strawberry purée treatments}

Individually quick frozen (IQF) strawberries [Fragaria $\times$ ananassa Duch. cv. 'Camarosa'] were blended to obtain purée. Strawberry purée was mixed with $0.25 \mathrm{~g} / \mathrm{L}$ of natamycin and $1.34 \mathrm{~g} / \mathrm{L}$ of potassium sorbate and $60 \mathrm{~g}$ were poured in serum type reaction glass vials of $100 \mathrm{~mL}$. Vials with the purée were pasteurised at $90{ }^{\circ} \mathrm{C}$ and the temperature at the centre of the vial, monitored with an HD 8802 thermometer (Delta OHM, Padova, Italy), reached $89.5^{\circ} \mathrm{C} \pm 2.2^{\circ} \mathrm{C}$ (mean $\pm \mathrm{SD}, n=20$ ) after $15 \mathrm{~min}$ and remained at that temperature for 5 min thereafter. The vials were then cooled to room temperature in ice during $5 \mathrm{~min}$. In a flow hood under aseptic conditions the vials with sample were flushed with a continuous flow at $40 \mathrm{kPa}$ of humidified air (control), $100 \mathrm{kPa} \mathrm{N}_{2}$ and $10 \mathrm{kPa} \mathrm{O}_{2}+90 \mathrm{kPa} \mathrm{N}$ and at the end of 3 min vials were crimped with aluminium seal with Teflon faced butyl septa. Vials were stored in dark for 90 days at room (ca. $23^{\circ} \mathrm{C}$ ) and cold temperature $\left(4^{\circ} \mathrm{C}\right)$.

Samples to perform extraction were taken in triplicates after $24 \mathrm{~h}$ and during storage (7, 14, 30, 60 and 90 days) for each atmosphere and temperature. The headspace gases were checked regularly with a PBI Dansensor CheckMate 3 (Dansensor, Ringsted, Denmark) throughout all storage period where a needle was plunged into the vials through septa to determine oxygen, carbon dioxide and nitrogen concentrations inside the package.

\subsection{Microbiological analysis}

The samples $(10 \mathrm{~mL})$ were homogenized in a stomacher (Model 400 Circulator, Seward, Norfolk, England) with peptone (Sigma, Sintra, Portugal) water (90 mL), serially diluted and plated on Plate
Count Agar (PCA, Biokar Diagnostics, Solabia, France) and incubated at $30{ }^{\circ} \mathrm{C}$ during $24 \mathrm{~h}$. Total yeasts and molds were also determined for the raw samples using Potato Dextrose Agar - PDA (Biokar Diagnostics, Solabia, France). The plates were incubated for 2 days at $30^{\circ} \mathrm{C}$. In both cases, colonies were enumerated and total viable cells (cfu/g) determined.

\subsection{Extracts preparation}

Polyphenols were extracted by maceration of $2.5 \mathrm{~g}$ of strawberry purée with $25 \mathrm{~mL}$ of aqueous methanolic solvent at $800 \mathrm{~mL} / \mathrm{L}$ using an ultra-turrax (IKA T18, Wilmington, USA) operated at $24,000 \mathrm{rpm}$ for $60 \mathrm{~s}$. The extract was centrifuged at $4000 \times \mathrm{g}, 4^{\circ} \mathrm{C}$ for $10 \mathrm{~min}$ and the supernatant filtered through a $0.45-\mu \mathrm{m}$ cellulose acetate filter (Orange Scientific, Braine-l'Alleud, Belgium) and used for total activities measurement. A $15-\mathrm{mL}$ aliquot of the supernatant was concentrated in an RVC 2-18 speed-vacuum evaporator (Christ, Osterode, Germany) at $30{ }^{\circ} \mathrm{C}$ and the residue dissolved in $4 \mathrm{~mL}$ of methanol and analysed by HPLC-DAD.

The same procedure was used for anthocyanins extraction, except that acidified methanol was used (methanol:water: $\mathrm{HCl}$ $12 \mathrm{~N}: 800 \mathrm{~mL}: 150 \mathrm{~mL}: 50 \mathrm{~mL})$.

\subsection{Total antioxidant activity}

The ABTS radical scavenging activity was measured in the nonacidified methanolic extracts using the method described by (Giao et al., 2007). Ascorbic acid was used as a standard to prepare a calibration curve in the range of $0.02-0.50 \mathrm{~g} / \mathrm{L}$.

\subsection{Analysis of total phenolic compounds}

The concentration of total phenolic compounds was determined spectrophotometrically by the Folin-Ciocalteu method (Singleton \& Rossi, 1965). Quantification was done at $750 \mathrm{~nm}$ (UV mini 1240, Shimadzu, Tokyo, Japan) with gallic acid as standard in the range 0.015-1.00 g/L.

\subsection{Analysis of total anthocyanins}

The concentration of total anthocyanins was determined spectrophotometrically by the $\mathrm{pH}$-differential method described by Lee, Durst, and Wrolstad (2005), with some modifications. Quantification was done at 515 and $700 \mathrm{~nm}$ at $\mathrm{pH} 1.0$ and $\mathrm{pH} 4.5$.

Results were expressed in accordance with Eq. (1) and converted to milligram of pelargonidin-3-glucoside per gram of biomass.

$A=\left(A_{515}-A_{700}\right)_{\mathrm{pH} 1.0}-\left(A_{515}-A_{700}\right)_{\mathrm{pH} 4.5}$

$c(\mathrm{mg} / \mathrm{l})=(A \times$ molecular weight $\times$ dilution factor $\times 1000) /(\varepsilon l)$

Molecular weight of pelargonidin-3-glucoside is $433.0 \mathrm{~g} / \mathrm{mol}$ and $\varepsilon$ is $22,400 \mathrm{~mol}^{-1}$

\subsection{Measurements of polyphenols}

Samples were analysed on an HPLC-DAD (Waters Series 600, Mildford, MA, USA). A Symmetry ${ }^{\circledR} \mathrm{C}-18$ column, $250 \times 4.6 \mathrm{~mm}$, i.d. $5 \mu \mathrm{m}$ and $12.5 \mathrm{~nm}$ pore size with a guard column (Waters), was used and solvents elution consisted of solvent $A$ - methanol/water/ formic acid (92.5:5:2.5 v/v/v) and solvent B - methanol/water $(94: 6 \mathrm{v} / \mathrm{v})$. For methanolic extracts, the linear gradient system starts on 0 and goes to $30 \% \mathrm{~B}$ in $40 \mathrm{~min}, 30-50 \% \mathrm{~B}$ in $20 \mathrm{~min}$ and from 50 to $0 \% \mathrm{~B}$ in $10 \mathrm{~min}$. For anthocyanins a linear gradient starts at 0 and 
goes to $30 \%$ B in $10 \mathrm{~min}$, from 30 to $50 \%$ B in 15 min and finally to $0 \%$ $\mathrm{B}$ in $5 \mathrm{~min}$ and kept at $0 \% \mathrm{~B}$ during $5 \mathrm{~min}$. The injection volume was $50 \mu \mathrm{L}$ with flow rate of $0.75 \mathrm{ml} / \mathrm{min}$ and a column temperature maintained at $25^{\circ} \mathrm{C}$.

Absorbance was measured at $280 \mathrm{~nm}((+)$-catechin and (-)-epicatechin), $350 \mathrm{~nm}$ (ellagic acid and quercetin-3-rutinoside) and $510 \mathrm{~nm}$ (cyanidin-3-glucoside, pelargonidin-3-glucoside and pelargonidin-3-rutinoside) with a diode array detector (Waters, Mildford, MA, USA). Quantifications were made by the use of pure standards and expressed as micrograms per gram of fresh biomass.

\subsection{Statistical analysis}

Statistical analysis was performed using GraphPad Prism version 5.00 for Windows. Normality of data distribution was tested by Kolmogorov-Smirnov method.

Statistical significance of differences among group means was evaluated by two-way analysis of variance with Bonferroni post hoc test at the $P<0.05$ level.

\section{Results and discussion}

\subsection{Headspace gas composition}

The variation of headspace gas partial percentages during the storage of pasteurised strawberry purée, packaged under different modified atmospheres ( $100 \mathrm{kPa} \mathrm{N}, 10 \mathrm{kPa} \mathrm{O}_{2}+90 \mathrm{kPa} \mathrm{N}$, and air) for 90 days storage at 4 and $23^{\circ} \mathrm{C}$ is presented on Fig. 1 .

Oxygen levels in the headspace vials were stable during storage under the conditions tested. Significant $(P<0.05)$ differences were detected, between both temperatures ( 4 and $23{ }^{\circ} \mathrm{C}$ ), in samples stored under air and $10 \mathrm{kPa} \mathrm{O}+90 \mathrm{kPa} \mathrm{N}$. Under air at the end of 90 days at $23{ }^{\circ} \mathrm{C}$ the oxygen level decreased from $19 \%$ to $18 \%$ while at $4{ }^{\circ} \mathrm{C}$ it was stable maintaining $20 \%$ oxygen. In $10 \mathrm{kPa} \mathrm{O}_{2}+90 \mathrm{kPa}$ $\mathrm{N}_{2}$, there was a decrease from $10 \mathrm{kPa} \mathrm{O}$ to $7.8 \mathrm{kPa}$ at $23^{\circ} \mathrm{C}$, while at $4{ }^{\circ} \mathrm{C}$ storage the levels of $10.0 \mathrm{kPa} \mathrm{O} 2$ was maintained (Fig. 1). The oxygen levels decrease revealed that oxygen was removed from the headspace and probably by dissolution in the matrix or consumed by oxidation reactions.

Carbon dioxide was only added to samples stored under air, but in the other atmospheres carbon dioxide was also detected inside the flasks in concentrations lower than $3 \mathrm{kPa}$. Besides that, there was a significant difference $(P<0.05)$ for both storage temperatures between days 7 and 90 , where higher concentrations were detected in samples stored at $23{ }^{\circ} \mathrm{C}$ (Fig. 1). Given that gases were added to the flask headspace, the increase in carbon dioxide observed at $23^{\circ} \mathrm{C}$ could be a result of $\mathrm{CO}_{2}$ transference from the purée air spaces to the flask headspace.

Nitrogen was stable during storage without differences between both storage temperatures (Fig. 1), and the nitrogen levels reach stability at day 15 of storage. It was observed that $100 \mathrm{kPa} \mathrm{N} 2$ decreased from 100 to $95 \mathrm{kPa}$ and then returns to $99 \mathrm{kPa}$. Under air, atmosphere reaches a stable value of $78 \mathrm{kPa}$ at day 15 while storage under $10 \mathrm{kPa}+90 \mathrm{kPa}$ at day zero presented $95 \mathrm{kPa}$, which decreased to $89 \mathrm{kPa}$. Nitrogen is an inert gas with low solubility in water and fat (Erkmen, 2012). These results revealed that about 15 days were necessary to reach equilibrium of nitrogen content in flask headspace.

\subsection{Total antioxidant activity, total phenolics and total anthocyanins}

Strawberry IQF was analysed for the initial antioxidant activity and content of total phenolic and total anthocyanins. The antioxidant activity determined by the ABTS was of $1.2 \pm 0.1 \mathrm{mg}$ of ascorbic
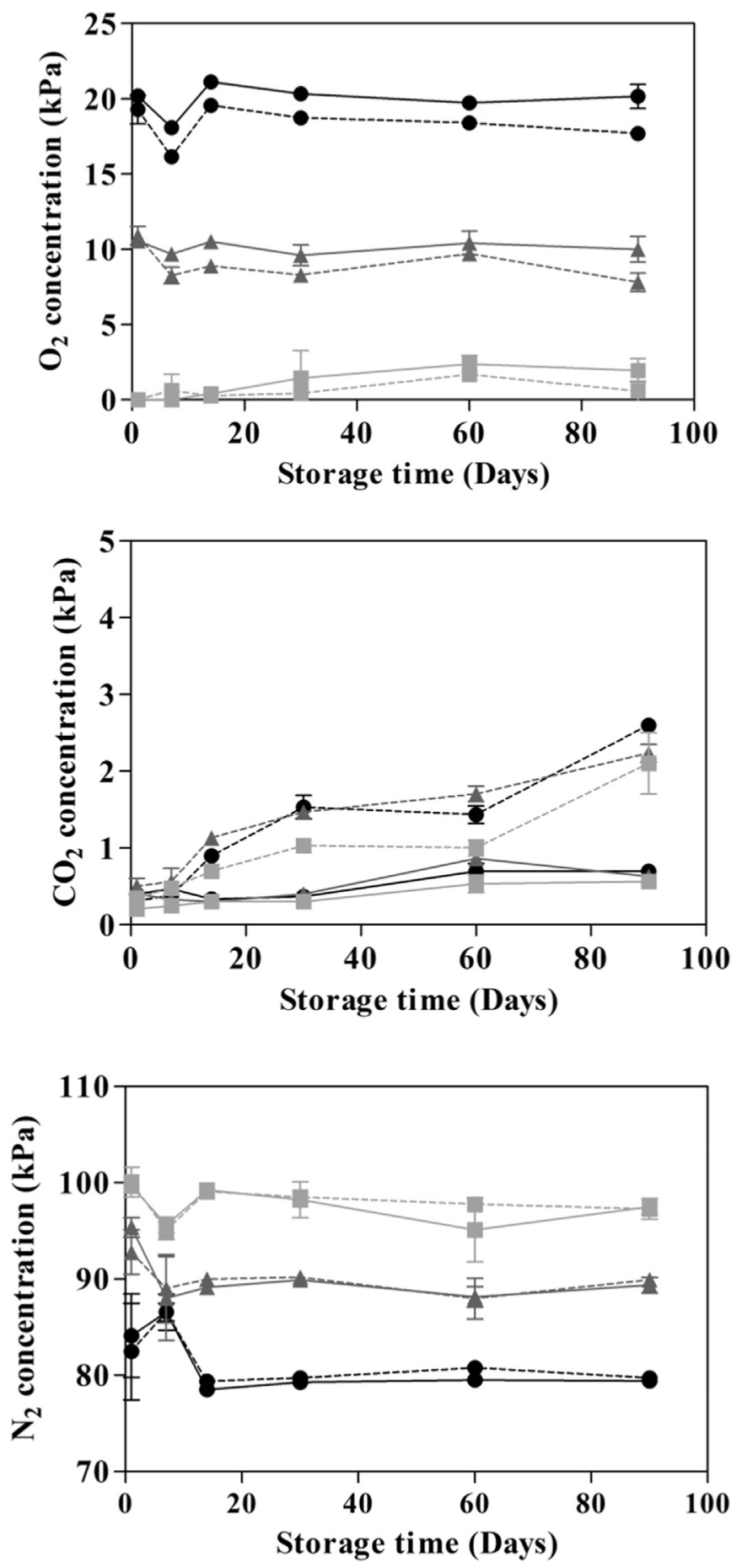

Fig. 1. Concentration of oxygen $\left(\mathrm{O}_{2}\right)$, carbon dioxide $\left(\mathrm{CO}_{2}\right)$ and nitrogen $\left(\mathrm{N}_{2}\right)$ for each modified atmosphere during storage of pasteurized strawberry purée stored at $4{ }^{\circ} \mathrm{C}$ $(-)$ and $23{ }^{\circ} \mathrm{C}(\cdots)$ for 90 days. Results are expressed as the average $\pm \mathrm{SD}(n=3)$. The different atmosphere conditions are represented as $\bullet$ : Air. $\square: 100 \mathrm{kPa} \mathrm{N}$. $4: 10 \mathrm{kPa}$ $\mathrm{PaO}_{2}+90 \mathrm{kPa} \mathrm{N}$.

acid/g biomass, the total phenolic content was $1.3 \pm 0.1 \mathrm{mg}$ of gallic acid/g biomass and total anthocyanins was $0.4 \pm 0.0 \mathrm{mg}$ of pelargonidin-3-glucoside/g biomass. Very similar values were obtained by Padula et al. (2013) for camarosa fresh strawberries, with a content of 1.4 and $0.4 \mathrm{mg} / \mathrm{g}$ biomass, respectively for total phenols and total anthocyanins. However, results obtained for antioxidant activity (3.5 mg of trolox/g fw) were higher because the 
determinations were made with a different standard as reference and with a different method. The DPPH method combines reactions of electron transfer with hydrogen atom transfer while ABTS only determine a single electron transfer reaction (Pérez-Jiménez et al., 2008).

Total antioxidant activity of strawberry purée was not affected during 90-day storage under different atmospheric conditions (air, $100 \mathrm{kPa} \mathrm{N} \mathrm{N}_{2}$ and $10 \mathrm{kPa} \mathrm{O}_{2}+90 \mathrm{kPa} \mathrm{N}$ ) (Tables 1 and 2). On the other hand, it was strongly affected by storage time and temperature, where at $4{ }^{\circ} \mathrm{C}$ decreased $35 \%$ for all atmospheric conditions and at $23{ }^{\circ} \mathrm{C}$ the reduction was of 50,53 and $58 \%$ for $100 \mathrm{kPa} \mathrm{N}$, $10 \mathrm{kPa} \mathrm{O}_{2}+90 \mathrm{kPa} \mathrm{N}$ and air, respectively.

As reported by Fernandes et al. (2013) and Georgé, Brat, Alter, and Amiot (2005) the Folin-Ciocalteu's assay is one of the oldest and accepted method designed to evaluate the total phenolic content in vegetal matrices. The method presents the major disadvantage of overestimating the polyphenol content, since the Folin-Ciocalteu reagent reacts with many reducing substances such as vitamin C, sugar, amino acids, etc (Everette et al., 2010). The total phenolic content of the strawberry samples was not affected by modified atmosphere (Tables 1 and 2). Under refrigerated storage $\left(4^{\circ} \mathrm{C}\right)$ total phenolic content decreased $38 \%$ for air and $31 \%$ for $100 \mathrm{kPa} \mathrm{N} 2$ and $10 \mathrm{kPa} \mathrm{O}+90 \mathrm{kPa} \mathrm{N} 2$. At $23{ }^{\circ} \mathrm{C}$ phenolic content decreased $40 \%$ for $100 \mathrm{kPa} \mathrm{N}, 53$ and $57 \%$ for $10 \mathrm{kPa} \mathrm{O}+90 \mathrm{kPa} \mathrm{N}$ and air, respectively.

Studies reported changes in antioxidant capacity promoted by modified atmosphere such as Kalt et al. (2000). They described a decrease of 30 and $46 \%$ in total antioxidant activity and total phenolic content in blueberry juice stored for $6 \mathrm{~h}$ in half-full vessels with air. Piljac-Žegarac, Valek, Martinez, and Belščak (2009) reported, antioxidant capacity decrease in strawberry, cranberry, blueberry and pomegranate juices stored under refrigeration for 29 days.

Storage under air, $10 \mathrm{kPa} \mathrm{O}_{2}$ or $100 \mathrm{kPa} \mathrm{N}_{2}$ was equivalent for antiradical capacity and total phenolics of strawberry purée. The best condition for storage was lower temperature $\left(4^{\circ} \mathrm{C}\right)$, since the

Table 1

Effect of modified atmosphere on antioxidant activity, total phenolic and total anthocyanin content of pasteurized strawberry purée stored at $4{ }^{\circ} \mathrm{C}$ for 90 days. Results are expressed as the average $\pm \mathrm{SD}(n=3)$ of concentration balance where $C_{t}$ is the compound concentration at time $t$ (mg/g biomass) and $C_{0}$ is the compound concentration at time 0 .

\begin{tabular}{llll}
\hline Storage time (days) & Air & $100 \mathrm{kPa} \mathrm{N} 2$ & $\begin{array}{l}10 \mathrm{kPa} \mathrm{O}_{2}+ \\
90 \mathrm{kPa} \mathrm{N}_{2}\end{array}$ \\
\hline Antioxidant activity $\left[\mathrm{C}_{\mathrm{t}} / \mathrm{C}_{0}\right]$ & & \\
1 & $1.0 \pm 0.0^{\mathrm{a}}$ & $1.0 \pm 0.1^{\mathrm{a}}$ & $1.0 \pm 0.0^{\mathrm{a}}$ \\
7 & $1.2 \pm 0.2^{\mathrm{a}}$ & $1.0 \pm 0.1^{\mathrm{a}}$ & $0.9 \pm 0.1^{\mathrm{b}}$ \\
14 & $1.0 \pm 0.0^{\mathrm{ac}}$ & $0.9 \pm 0.1^{\mathrm{a}}$ & $1.0 \pm 0.1^{\mathrm{a}}$ \\
30 & $0.8 \pm 0.0^{\mathrm{a}}$ & $0.8 \pm 0.0^{\mathrm{a}}$ & $0.7 \pm 0.0^{\mathrm{a}}$ \\
60 & $0.7 \pm 0.0^{\mathrm{a}}$ & $0.7 \pm 0.0^{\mathrm{a}}$ & $0.7 \pm 0.0^{\mathrm{a}}$ \\
90 & $0.7 \pm 0.0^{\mathrm{a}}$ & $0.7 \pm 0.0^{\mathrm{a}}$ & $0.6 \pm 0.0^{\mathrm{a}}$ \\
Total phenolics $\left[\mathrm{C}_{\mathrm{t}} / \mathrm{C}_{0}\right]$ & & & \\
1 & $1.0 \pm 0.2^{\mathrm{a}}$ & $1.0 \pm 0.1^{\mathrm{a}}$ & $1.0 \pm 0.0^{\mathrm{a}}$ \\
7 & $0.9 \pm 0.0^{\mathrm{a}}$ & $1.0 \pm 0.0^{\mathrm{a}}$ & $0.9 \pm 0.0^{\mathrm{a}}$ \\
14 & $0.9 \pm 0.0^{\mathrm{a}}$ & $1.0 \pm 0.0^{\mathrm{a}}$ & $1.1 \pm 0.1^{\mathrm{a}}$ \\
30 & $0.9 \pm 0.0^{\mathrm{a}}$ & $1.0 \pm 0.0^{\mathrm{a}}$ & $1.0 \pm 0.0^{\mathrm{a}}$ \\
60 & $0.8 \pm 0.0^{\mathrm{a}}$ & $1.0 \pm 0.1^{\mathrm{a}}$ & $0.9 \pm 0.1^{\mathrm{b}}$ \\
90 & $0.6 \pm 0.0^{\mathrm{a}}$ & $0.7 \pm 0.0^{\mathrm{a}}$ & $0.7 \pm 0.0^{\mathrm{a}}$ \\
Total anthocyanins $\left[C_{\mathrm{t}} / C_{0}\right]$ & & \\
1 & $1.0 \pm 0.0^{\mathrm{a}}$ & $1.0 \pm 0.0^{\mathrm{a}}$ & $1.0 \pm 0.0^{\mathrm{a}}$ \\
7 & $1.0 \pm 0.0^{\mathrm{a}}$ & $1.0 \pm 0.0^{\mathrm{a}}$ & $0.9 \pm 0.0^{\mathrm{a}}$ \\
14 & $1.0 \pm 0.0^{\mathrm{ab}}$ & $1.0 \pm 0.0^{\mathrm{a}}$ & $0.9 \pm 0.0^{\mathrm{b}}$ \\
30 & $0.9 \pm 0.0^{\mathrm{ab}}$ & $0.9 \pm 0.0^{\mathrm{b}}$ & $1.0 \pm 0.0^{\mathrm{a}}$ \\
60 & $0.8 \pm 0.0^{\mathrm{b}}$ & $0.9 \pm 0.0^{\mathrm{ac}}$ & $0.8 \pm 0.0^{\mathrm{c}}$ \\
90 & $0.7 \pm 0.0^{\mathrm{b}}$ & $0.8 \pm 0.0^{\mathrm{ac}}$ & $0.7 \pm 0.0^{\mathrm{c}}$ \\
\hline
\end{tabular}

a,b,c Different letters represents significant $(P<0.05)$ differences between packaging atmospheres for each storage day.

\section{Table 2}

Effect of modified atmosphere on antioxidant activity, total phenolic and total anthocyanin content of pasteurized strawberry purée stored at $23{ }^{\circ} \mathrm{C}$ for 90 days. Results are expressed as the average $\pm \operatorname{SD}(n=3)$ of concentration balance where $C_{t}$ is the compound concentration at time $t\left(\mathrm{mg} / \mathrm{g}\right.$ biomass) and $C_{0}$ is the compound concentration at time 0 .

\begin{tabular}{llll}
\hline Storage time (days) & Air & $100 \mathrm{kPa} \mathrm{N}_{2}$ & $\begin{array}{l}10 \mathrm{kPa} \mathrm{O}_{2}+ \\
90 \mathrm{kPa} \mathrm{N}_{2}\end{array}$ \\
\hline Antioxidant activity $\left[\mathrm{C}_{\mathrm{t}} / \mathrm{C}_{0}\right]$ & & \\
1 & $1.0 \pm 0.1^{\mathrm{a}}$ & $1.0 \pm 0.0^{\mathrm{a}}$ & $1.0 \pm 0.1^{\mathrm{a}}$ \\
7 & $0.8 \pm 0.0^{\mathrm{b}}$ & $1.0 \pm 0.2^{\mathrm{a}}$ & $0.9 \pm 0.0^{\mathrm{ab}}$ \\
14 & $0.7 \pm 0.0^{\mathrm{b}}$ & $0.9 \pm 0.0^{\mathrm{a}}$ & $0.8 \pm 0.0^{\mathrm{ab}}$ \\
30 & $0.6 \pm 0.0^{\mathrm{a}}$ & $0.7 \pm 0.0^{\mathrm{a}}$ & $0.6 \pm 0.0^{\mathrm{a}}$ \\
60 & $0.4 \pm 0.0^{\mathrm{b}}$ & $0.6 \pm 0.1^{\mathrm{a}}$ & $0.6 \pm 0.1^{\mathrm{a}}$ \\
90 & $0.4 \pm 0.0^{\mathrm{a}}$ & $0.5 \pm 0.1^{\mathrm{a}}$ & $0.5 \pm 0.0^{\mathrm{a}}$ \\
Total phenolics $\left[\mathrm{C}_{\mathrm{t}} / \mathrm{C}_{0}\right]$ & & & \\
1 & $1.0 \pm 0.1^{\mathrm{a}}$ & $1.0 \pm 0.1^{\mathrm{a}}$ & $1.0 \pm 0.0^{\mathrm{a}}$ \\
7 & $0.9 \pm 0.0^{\mathrm{a}}$ & $1.0 \pm 0.0^{\mathrm{a}}$ & $0.9 \pm 0.1^{\mathrm{a}}$ \\
14 & $0.8 \pm 0.1^{\mathrm{a}}$ & $1.0 \pm 0.0^{\mathrm{a}}$ & $0.9 \pm 0.1^{\mathrm{a}}$ \\
30 & $0.6 \pm 0.1^{\mathrm{b}}$ & $0.9 \pm 0.0^{\mathrm{a}}$ & $0.8 \pm 0.0^{\mathrm{b}}$ \\
60 & $0.7 \pm 0.1^{\mathrm{ab}}$ & $0.9 \pm 0.1^{\mathrm{a}}$ & $0.6 \pm 0.1^{\mathrm{b}}$ \\
90 & $0.4 \pm 0.0^{\mathrm{b}}$ & $0.6 \pm 0.0^{\mathrm{b}}$ & $0.5 \pm 0.0^{\mathrm{b}}$ \\
Total anthocyanins $\left[\mathrm{C}_{\mathrm{t}} / \mathrm{C}_{0}\right]$ & & & \\
1 & $1.0 \pm 0.0^{\mathrm{a}}$ & $1.0 \pm 0.0^{\mathrm{a}}$ & $1.0 \pm 0.0^{\mathrm{a}}$ \\
7 & $0.8 \pm 0.0^{\mathrm{a}}$ & $0.9 \pm 0.0^{\mathrm{a}}$ & $0.9 \pm 0.1^{\mathrm{a}}$ \\
14 & $0.6 \pm 0.0^{\mathrm{b}}$ & $0.8 \pm 0.0^{\mathrm{a}}$ & $0.7 \pm 0.0^{\mathrm{b}}$ \\
30 & $0.5 \pm 0.0^{\mathrm{b}}$ & $0.7 \pm 0.0^{\mathrm{a}}$ & $0.5 \pm 0.0^{\mathrm{b}}$ \\
60 & $0.2 \pm 0.0^{\mathrm{c}}$ & $0.5 \pm 0.1^{\mathrm{a}}$ & $0.4 \pm 0.2^{\mathrm{bc}}$ \\
90 & $0.1 \pm 0.0^{\mathrm{c}}$ & $0.2 \pm 0.1^{\mathrm{a}}$ & $0.2 \pm 0.0^{\mathrm{c}}$ \\
\hline $\mathrm{b}$ & & & \\
\hline
\end{tabular}

a,b,c Different letters represents significant $(P<0.05)$ differences between packaging atmospheres for each storage day.

observed decreases were all inferior to $40 \%$, in detriment of room temperature.

Total anthocyanins content also changed exhibiting a similar pattern as observed for total antioxidant activity and total phenolic content during storage in response to different atmospheric treatments. At $4{ }^{\circ} \mathrm{C}$, after 90 days, total anthocyanins content decreased $35 \%$ in air, which was significantly different $(P<0.05)$ from samples stored at $100 \mathrm{kPa} \mathrm{N}$ and $10 \mathrm{kPa} \mathrm{O}_{2}+90 \mathrm{kPa} \mathrm{N}$, which decreased 24 and $29 \%$, respectively. At $23{ }^{\circ} \mathrm{C}$ samples stored under $100 \mathrm{kPa} \mathrm{N}$ decreased 77\%, which was significantly $(P<0.05)$ lower than $10 \mathrm{kPa}$ $\mathrm{O}_{2}+90 \mathrm{kPa} \mathrm{N}$ and air, where it decreased 82 and $86 \%$, respectively (Tables 1 and 2).

Lower oxygen content as well refrigerated temperature $\left(4^{\circ} \mathrm{C}\right)$ were the better conditions to achieve strawberry purée with higher anthocyanins content. Oxygen has been reported to be an important factor in destabilizing anthocyanins in processed products such as strawberry juices (Francis \& Markakis, 1989; Nebesky, Esselen, Mc Connell, \& Fellers, 1949). Clydesdale, Main, Francis, and Damon (1978) reported an increased stability of grape pigments in a dry beverage mix by flushing with nitrogen.

Shikov, Kammerer, Mihalev, Mollov, and Carle (2008) observed that lowering storage temperature from 20 to $4{ }^{\circ} \mathrm{C}$ in strawberry purée was the most effective measure to improve anthocyanins retention over time. Storage of strawberry jams, during 24 weeks at 20 and $4{ }^{\circ} \mathrm{C}$, presented a significantly decline in total and individual anthocyanin contents (Shikov, Kammerer, Mihalev, Mollov, \& Carle, 2012). Buchweitz, Carle, and Kammerer (2012) observed a 10\% decrease in anthocyanins of strawberry stored 18 weeks at $20^{\circ} \mathrm{C}$ in the dark.

\subsection{Individual phytochemicals content during storage}

High-performance liquid chromatography (HPLC) was used to separate and determine individual phenolic compounds in strawberry purée samples.

The (+)-catechin presented an initial concentration, on IQF samples, of $43.9 \pm 4.1 \mu \mathrm{g} / \mathrm{g}$ similar to the values of $58.6 \mu \mathrm{g} / \mathrm{g}$ 
obtained by Padula et al. (2013) in fresh strawberry. At $4{ }^{\circ} \mathrm{C}$, $(+)$-catechin presented high stability during 90 days-storage (Fig. 2A), contrarily to samples stored at $23{ }^{\circ} \mathrm{C}$ where air led to a significant $(P<0.05)$ decrease of $45 \%$ after 30 days of storage. In $10 \mathrm{kPa} \mathrm{O}_{2}+90 \mathrm{kPa} \mathrm{N}$ and $100 \mathrm{kPa} \mathrm{N}$ the observed decrease was only $16 \%$ (Fig. 3A). (-)-Epicatechin did not shown differences between the atmospheres for both temperatures. At $4{ }^{\circ} \mathrm{C}$, (-)-epicatechin concentration decreased $9 \%$ under $100 \mathrm{kPa} \mathrm{N}$, $4 \%$ for $10 \mathrm{kPa} \mathrm{O}_{2}+90 \mathrm{kPa} \mathrm{N} 2$ and $10 \%$ for air at the end of storage. At $23{ }^{\circ} \mathrm{C}$ it decreased $61 \%$ under anerobiosis (100 $\mathrm{kPa} \mathrm{N}_{2}$ ), followed by $45 \%$ for $10 \mathrm{kPa} \mathrm{O}_{2}+90 \mathrm{kPa} \mathrm{N}_{2}$ and $30 \%$ for air (Figs. 2B and 3B).

Polyphenols from green and black teas show a pronounced oxygen consumption leading to autoxidation of compounds like epicatechin, epigallocatechin, epicatechin gallate and epigallocatechin gallate (Roginsky \& Alegria, 2005). Similar behaviour is reported for autoxidation of tea catechins, which showed to be highly endothermic, so elevation of temperature stimulates oxidation reactions (Roginsky \& Alegria, 2005; Roginsky \& Barsukova, 2000).
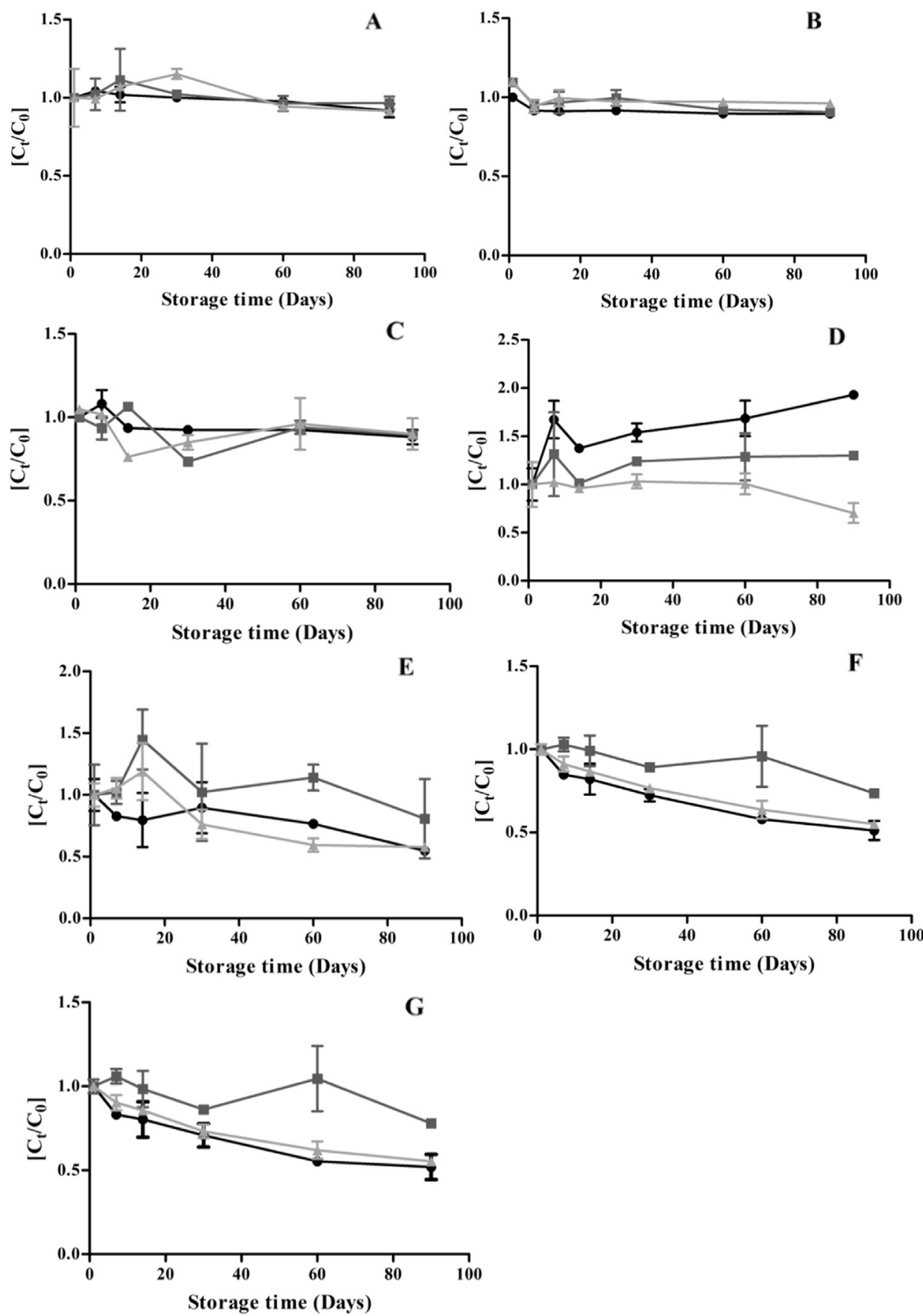

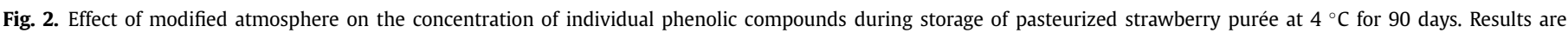

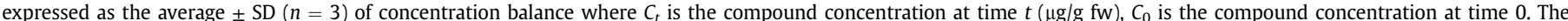

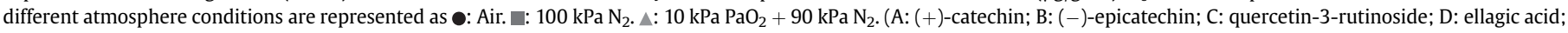
E: cyanidin-3-glucoside; F: pelargonidin-3-glucoside; G: pelargonidin-3-rutinoside). 

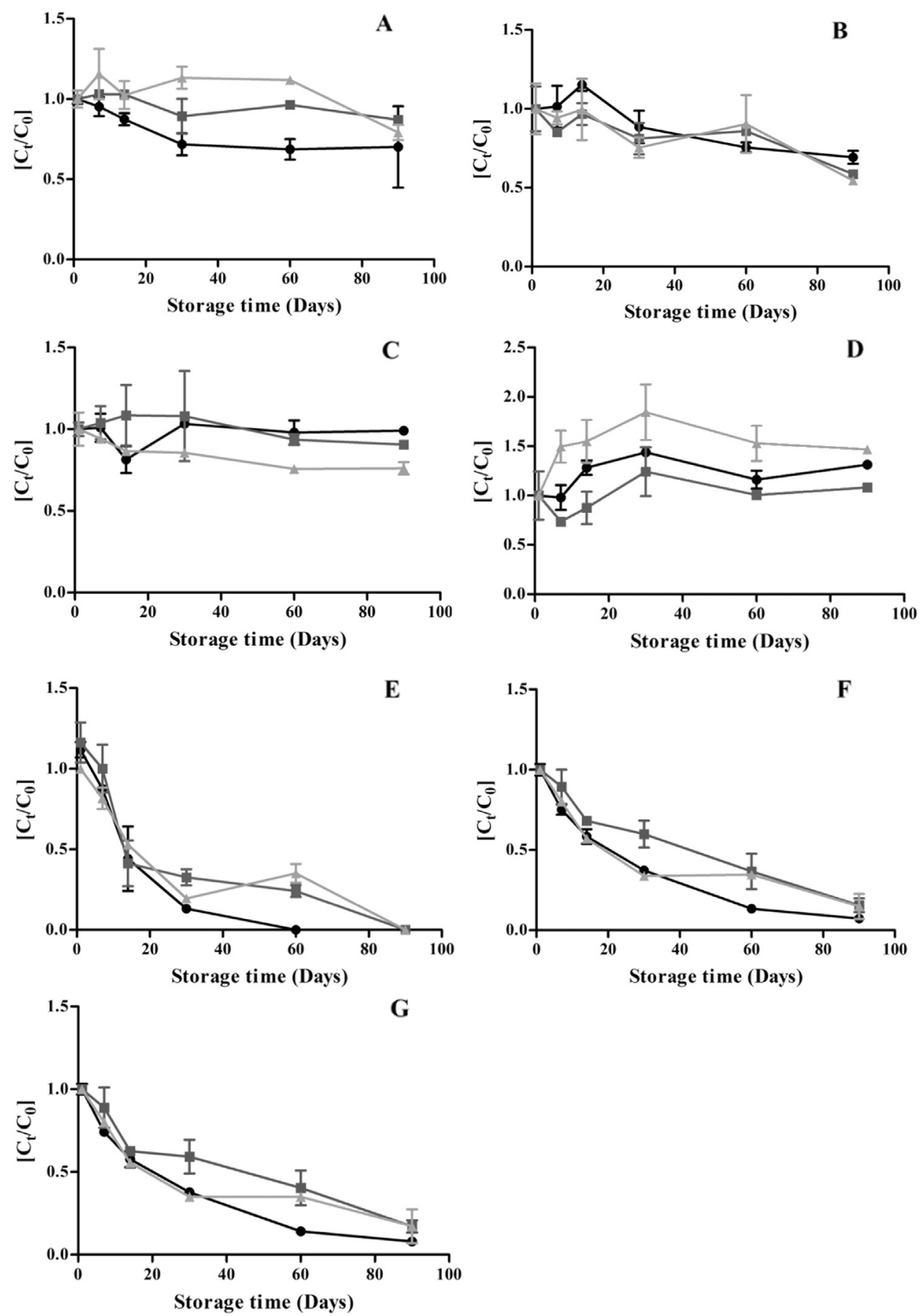

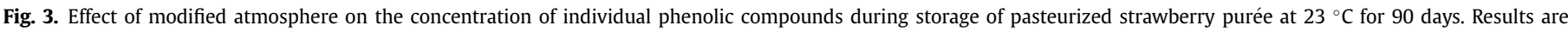

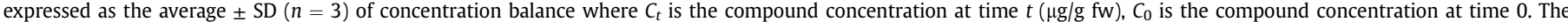

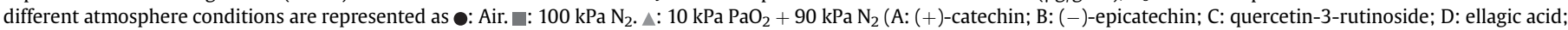
E: cyanidin-3-glucoside; F: pelargonidin-3-glucoside; G: pelargonidin-3-rutinoside).

Cheynier (2005) reported that flavanols can form dimeric adducts with anthocyanins by two types of chemical reactions. One involves cleavage of the tannin interflavanic linkage, followed by nucleophilic addition of the anthocyanin hemiketal to the carbocation. Second the anthocyanin and flavanol units can be linked by both carbon-carbon ( $\mathrm{C} 4-\mathrm{C} 8)$ and ether $(\mathrm{C} 2-\mathrm{O}-\mathrm{C} 7)$ bonds (Atype), formed by nucleophilic addition of the flavanol to the anthocyanin flavylium cation.

The anthocyanins identified in strawberry were cyanidin-3glucoside, pelargonidin-3-glucoside and pelargonidin-3-rutino side and their concentration on IQF samples were of $5.0 \pm 0.4$, $298 \pm 52$ and $22.2 \pm 0.4 \mu \mathrm{g} / \mathrm{g}$ biomass, respectively. Padula et al. (2013) describe, on camarosa strawberries, a content of 28.6, 179 and $22.9 \mu \mathrm{g} / \mathrm{g}$ respectively for cyanidin-3-O-glucoside, pelargonidin-3-O-glucoside and pelargonidin-3-O-rutinoside. da Silva, Escribano-Bailón, Pérez Alonso, Rivas-Gonzalo, and Santos-Buelga (2007) reported a higher content in cyanidin-3-glucoside $(25 \mu \mathrm{g} /$ g) and pelargonidin-3-rutinoside $(43 \mu \mathrm{g} / \mathrm{g})$, while pelargonidin-3glucoside content was very similar to our results, with $261 \mu \mathrm{g} / \mathrm{g}$ for fresh strawberry. However, these discrepancies are expected 
due to the differences in climate conditions during production that inevitably affect the antioxidant compounds profile.

All the strawberry anthocyanins showed an increased degradation with the increase in oxygen levels. Cyanidin-3-glucoside decreased $20 \%$ when samples were stored under $100 \mathrm{kPa} \mathrm{N}_{2}$ and $43 \%$ for storage under $10 \mathrm{kPa} \mathrm{O} \mathrm{O}_{2}+90 \mathrm{kPa} \mathrm{N}$ and air at $4{ }^{\circ} \mathrm{C}$ (Fig. 2E). When samples were stored 90 days at $23{ }^{\circ} \mathrm{C}$, cyanidin-3-glucoside decreased at levels below the detection limit for all the atmospheres tested (Fig. 3E).

The pelargonidin-3-glucoside content decreased 27\% when strawberry purée was stored under $100 \mathrm{kPa} \mathrm{N} \mathrm{N}_{2}$ at $4{ }^{\circ} \mathrm{C}$. The other $2 \mathrm{~atm}$ tested induced a decrease of $45 \%$ (Fig. 2F). The $100 \mathrm{kPa} \mathrm{N}$ allowed higher $(P<0.05)$ retention of pelargonidin-3-glucoside than air and $10 \mathrm{kPa} \mathrm{O} \mathrm{O}_{2}+90 \mathrm{kPa} \mathrm{N} 2$. For $23{ }^{\circ} \mathrm{C}$, pelargonidin-3glucoside decrease $85 \%$ for $100 \mathrm{kPa} \mathrm{N} \mathrm{N}_{2}$ while for $10 \mathrm{kPa}$ $\mathrm{O}_{2}+90 \mathrm{kPa} \mathrm{N} \mathrm{N}_{2}$ and air the decrease raised to 99.3\% (Fig. 2F).

The $100 \mathrm{kPa} \mathrm{N} 2$ allowed higher retention, at $4{ }^{\circ} \mathrm{C}$, with a decrease of $23 \%$. For the conditions of $10 \mathrm{kPa} \mathrm{O}_{2}+90 \mathrm{kPa} \mathrm{N} \mathrm{N}_{2}$ and air pelargonidin-3-rutinoside decreased $45 \%$ (Fig. 2G). Room temperature $\left(23^{\circ} \mathrm{C}\right)$ induced higher reductions corresponding to $83 \%$ for $100 \mathrm{kPa}$ $\mathrm{N}_{2}$ and $99.3 \%$ for $10 \mathrm{kPa} \mathrm{O} \mathrm{O}_{2}+90 \mathrm{kPa} \mathrm{N}$ and air, without differences between them (Fig. 3G).

The deleterious effects of molecular oxygen on anthocyanins have been observed by a number of researchers. Oxygen and temperature were the most specific accelerating factors in the degradation of anthocyanins (Nebesky et al., 1949). Others reports describe that the replacement of the oxygen atmosphere with nitrogen enhance the stability of cyanidin-3-diglucoside, a natural berry juice pigment (Daravingas \& Cain, 1968). Oxygen incorporation into blueberry juice has a marked effect on monomeric anthocyanins with 76\% loss after 6 h storage (Kalt et al., 2000) and it was considered a destabilizing agent for anthocyanins from processed products of blueberry juice (Francis \& Markakis, 1989).

Oxygen may cause deleterious effects through a direct oxidative mechanism and/or trough indirect oxidation. Oxidized constituents of the medium, such as furfural-type compounds resultant from sugars degradation, are capable of reacting and/or condense with anthocyanins to form complex brown coloured compounds (Jackman, Yada, Tung, \& Speers, 1987).

Aerobic oxidation of ascorbic acid promotes anthocyanins degradation (Sondheimer \& Kertesz, 1953), as well condensation between ascorbic acid and anthocyanins as reported for strawberry juice (Markaris, Livingston, \& Fellers, 1957).

The interaction between pelargonidin-3-glucoside, catechin and ascorbic acid is also observed, in model systems where ascorbic acid accelerates anthocyanin loss in samples stored under nitrogen as well as those stored under oxygenated conditions (PoeiLangston \& Wrolstad, 1981; Sondheimer \& Kertesz, 1953).

Quercetin-3-rutinoside concentration, at $4{ }^{\circ} \mathrm{C}$, decreased $10 \%$ in all atmospheric conditions without significant differences along the storage period. At $23^{\circ} \mathrm{C}$ quercetin-3-rutinoside decreased $1 \%$ when stored in air, $10 \%$ in $100 \mathrm{kPa} \mathrm{N}$ and $24 \%$ in $10 \mathrm{kPa} \mathrm{O} 2+90 \mathrm{kPa} \mathrm{N}$ The only significant differences $(P<0.05)$ were obtained for $10 \mathrm{kPa}$ $\mathrm{O}_{2}+90 \mathrm{kPa} \mathrm{N}$ and air between day 60 and 90 of storage.

Buchner, Krumbein, Rohn, and Kroh (2006) showed that presence of oxygen highly induces quercetin and rutin degradation, while the absence of oxygen has the opposite effects.

Quercetin of strawberry juices decreased progressively at $4{ }^{\circ} \mathrm{C}$ in darkness over 56 days (Odriozola-Serrano, Soliva-Fortuny, \& Martin-Belloso, 2009).

Ellagic acid, is formed through the association of two molecules of gallic acid in the presence of oxygen and the dimer of gallic acid spontaneously forms ellagic acid when acidified (Tulyathan, Boulton, \& Singleton, 1989). The initial concentration determined on IQF samples was of $12.7 \pm 0.4 \mu \mathrm{g} / \mathrm{g}$ fw. It have been reported a great variety of concentrations for ellagic acid in camarosa strawberries, such as $6.1 \mu \mathrm{g} / \mathrm{g}$ (Van De Velde, Tarola, Güemes, \& Pirovani, 2013), $22 \mu \mathrm{g} / \mathrm{g}$ (da Silva Pinto, Lajolo, \& Genovese, 2008) and $1193 \mu \mathrm{g} / \mathrm{g}$ for fresh strawberries (Bojarska, Zadernowski, \& Czaplicki, 2011). The storage at $4{ }^{\circ} \mathrm{C}$ revealed an increase of $92 \%$ for air, 30\% decrease for $10 \mathrm{kPa} \mathrm{O}_{2}+90 \mathrm{kPa} \mathrm{N} 2$ and 30\% increase for $100 \mathrm{kPa} \mathrm{N} \mathrm{N}_{2}$. The differences $(P<0.05)$ registered between three atmospheres occurred only between day 60 and 90 of storage. At $23^{\circ} \mathrm{C}$ ellagic concentration increased 8,47 and $31 \%$, respectively for $100 \mathrm{kPa} \mathrm{N}, 10 \mathrm{kPa} \mathrm{O}_{2}+90 \mathrm{kPa} \mathrm{N} \mathrm{N}_{2}$ and air. The concentration variations observed, at $23{ }^{\circ} \mathrm{C}$ in the end of 90 days, were not significantly different between them.

One of the reasons proposed for ellagic acid increase can be ellagitannins degradation caused by combination of thermal treatment and storage time (Aaby, Skrede, \& Wrolstad, 2005; Häkkinen, Kärenlampi, Mykkänen, Heinonen, \& Törrönen, 2000; Zafrilla et al., 2003).

The antioxidant capacity as well total phenolic content are associated with hydroxyl groups of a molecule and so depends on phenolic compound chemical structure, namely the number and arrangement of the hydroxylated groups (Rice-Evans, Miller, \& Paganga, 1996; Sang et al., 2002).

However the individual compounds as a whole can reproduce a constant signal as observed for total activities, besides the variation observed in their concentration along storage.

Strawberry purée $\mathrm{pH}$ values were kept constant during storage starting with $3.8 \pm 0.00$ and ending at $3.5 \pm 0.05$ for all atmospheric conditions and temperatures tested, revealing no potential interferences in polyphenols chemical transformations.

In the experiment there were no detections of microbial growth (mesophilic bacteria or yeast) in strawberry purées, confirming that sterile conditions were assured, and consequently the microbial metabolism was not interfering with degradation reactions.

\section{Conclusions}

Modified atmosphere allowed higher stability on total antioxidant activity, total phenolic and total anthocyanins content of strawberry purée. Among individual phenolic compounds the most affected by atmospheric conditions were anthocyanins, while catechins and quercetin-rutinoside were the most stable. Anthocyanins decreased at a faster rate for samples stored in air.

The conditions that can be recommended for preservation of nutritional properties during purée strawberry storage are refrigerated temperature conditions $\left(4^{\circ} \mathrm{C}\right)$ and an anaerobic atmosphere $\left(100 \% \mathrm{~N}_{2}\right)$ since under these conditions the concentration of strawberry colouring polyphenols (anthocyanins) would be higher and compounds like $(+)$-catechin, (-)-epicatechin, quercetin-3rutinoside and ellagic acid would be more stable.

\section{Funding}

The work was financially supported by Agência de Inovação, Portugal and Quadro de Referência Estratégico Nacional (QREN Portugal) through project Frutamais - Preservation of functional nutritional and organoleptic characteristic of fruits and derived food (QREN-ADI 3436), FCT - Fundação para a Ciência e a Tecnologia through project PEst-OE/EQB/LA0016/2013 and by the PhD grant SFRH/BD/75041/2010 to A. Oliveira.

\section{References}

Aaby, K., Skrede, G., \& Wrolstad, R. E. (2005). Phenolic composition and antioxidant activities in flesh and achenes of strawberries (Fragaria ananassa). Journal of Agricultural and Food Chemistry, 53(10), 4032-4040. 
Aguilar-Rosas, S. F., Ballinas-Casarrubias, M. L., Nevarez-Moorillon, G. V., MartinBelloso, O., \& Ortega-Rivas, E. (2007). Thermal and pulsed electric fields pasteurization of apple juice: effects on physicochemical properties and flavour compounds. Journal of Food Engineering, 83(1), 41-46.

Alwazeer, D., Delbeau, C., Divies, C., \& Cachon, R. (2003). Use of redox potential modification by gas improves microbial quality, color retention, and ascorbic acid stability of pasteurized orange juice. International Journal of Food Microbiology, 89(1), 21-29.

Bojarska, J. E., Zadernowski, R., \& Czaplicki, S. (2011). Ellagic acid content in fruits of selected strawberry cultivars. Polish Journal of Natural Sciences, 26, 171-177.

Buchner, N., Krumbein, A., Rohn, S., \& Kroh, L. W. (2006). Effect of thermal processing on the flavonols rutin and quercetin. Rapid Communications in Mass Spectrometry, 20(21), 3229-3235.

Buchweitz, M., Carle, R., \& Kammerer, D. R. (2012). Bathochromic and stabilising effects of sugar beet pectin and an isolated pectic fraction on anthocyanins exhibiting pyrogallol and catechol moieties. Food Chemistry, 135(4), 3010-3019.

Cheynier, V. (2005). Polyphenols in foods are more complex than often thought. The American Journal of Clinical Nutrition, 81(1), 223S-229S.

Clydesdale, F. M., Main, J. H., Francis, F. J., \& Damon, R. A. (1978). Concord grape pigments as colorants for beverages and gelatin desserts. Journal of Food Science, 43(6), 1687-1692.

Daravingas, G., \& Cain, R. F. (1968). Thermal degradation of black raspberry anthocyanin pigments in model systems. Journal of Food Science, 33(2), $138-142$.

Erkmen, O. (2012). 3 modified-atmosphere storage of foods. Progress in food preservation (p. 49).

Everette, J. D., Bryant, Q. M., Green, A. M., Abbey, Y. A., Wangila, G. W., \& Walker, R. B. (2010). Thorough study of reactivity of various compound classes toward the Folin- Ciocalteu reagent. Journal of Agricultural and Food Chemistry, 58(14), 8139-8144.

Farber, J. N., Harris, L. J., Parish, M. E., Beuchat, L. R., Suslow, T. V., Gorney, J. R., et al. (2003). Microbiological safety of controlled and modified atmosphere packaging of fresh and fresh-cut produce. Comprehensive Reviews in Food Science and Food Safety, 2, 142-160.

Fernandes, F., Ramalhosa, E., Pires, P., Verdial, J., Valentão, P., Andrade, P., et al. (2013). Vitis vinifera leaves towards bioactivity. Industrial Crops and Products, 43(0), 434-440.

Francis, F. J., \& Markakis, P. C. (1989). Food colorants: anthocyanins. Critical Reviews in Food Science \& Nutrition, 28(4), 273-314.

García-Torres, R., Ponagandla, N. R., Rouseff, R. L., Goodrich-Schneider, R. M., \& Reyes-De-Corcuera, J. I. (2009). Effects of dissolved oxygen in fruit juices and methods of removal. Comprehensive Reviews in Food Science and Food Safety, $8(4), 409-423$.

Georgé, S., Brat, P., Alter, P., \& Amiot, M. J. (2005). Rapid determination of polyphenols and vitamin $C$ in plant-derived products. Journal of Agricultural and Food Chemistry, 53(5), 1370-1373.

Giao, M. S., Gonzalez-Sanjose, M. L., Rivero-Perez, M. D., Pereira, C. I., Pintado, M. E., \& Malcata, F. X. (2007). Infusions of portuguese medicinal plants: dependence of final antioxidant capacity and phenol content on extraction features. Journal of the Science of Food and Agriculture, 87(14), 2638-2647.

Häkkinen, S. H., Kärenlampi, S. O., Mykkänen, H. M., Heinonen, I. M., \& Törrönen, A. R. (2000). Ellagic acid content in berries: influence of domestic processing and storage. European Food Research and Technology, 212(1), 75-80.

Ioannou, I., Hafsa, I., Hamdi, S., Charbonnel, C., \& Ghoul, M. (2012). Review of the effects of food processing and formulation on flavonol and anthocyanin behaviour. Journal of Food Engineering, 111(2), 208-217.

Jackman, R. L., Yada, R. Y., Tung, M. A., \& Speers, R. A. (1987). Anthocyanins as food colorants-a review. Journal of Food Biochemistry, 11(3), 201-247.

Kalt, W., McDonald, J. E., \& Donner, H. (2000). Anthocyanins, phenolics, and antioxidant capacity of processed lowbush blueberry products. Journal of Food Science, 65(3), 390-393.

Klopotek, Y., Otto, K., \& Bohm, V. (2005). Processing strawberries to different products alters contents of vitamin C, total phenolics, total anthocyanins, and antioxidant capacity. Journal of Agricultural and Food Chemistry, 53(14), $5640-5646$.

Lee, J., Durst, R. W., \& Wrolstad, R. E. (2005). Determination of total monomeric anthocyanin pigment content of fruit juices, beverages, natural colorants, and wines by the $\mathrm{pH}$ differential method: collaborative study. Journal of AOAC International, 88(5), 1269-1278.
Markaris, P., Livingston, G. E., \& Fellers, C. R. (1957). Quantitative aspects of strawberry pigment degradation. Journal of Food Science, 22(2), 117-130.

Nebesky, E. A., Esselen, W. B., Mc Connell, J. E. W., \& Fellers, C. R. (1949). Stability of color in fruit juices. Journal of Food Science, 14(3), 261-274.

Odriozola-Serrano, I., Soliva-Fortuny, R., \& Martin-Belloso, O. (2009). Influence of storage temperature on the kinetics of the changes in anthocyanins, vitamin C, and antioxidant capacity in fresh-cut strawberries stored under high-oxygen atmospheres [Research Support, Non-U.S. Gov't] Journal of Food Science, 74(2), C184-C191.

Padula, M. C., Lepore, L., Milella, L., Ovesna, J., Malafronte, N., Martelli, G., et al. (2013). Cultivar based selection and genetic analysis of strawberry fruits with high levels of health promoting compounds. Food Chemistry, 140(4), 639-646.

Pérez-Jiménez, J., Arranz, S., Tabernero, M., Díaz-Rubio, M. E., Serrano, J., Goñi, I., et al. (2008). Updated methodology to determine antioxidant capacity in plant foods, oils and beverages: extraction, measurement and expression of results. Food Research International, 41(3), 274-285.

Piljac-Žegarac, J., Valek, L., Martinez, S., \& Belščak, A. (2009). Fluctuations in the phenolic content and antioxidant capacity of dark fruit juices in refrigerated storage. Food Chemistry, 113(2), 394-400.

Poei-Langston, M. S., \& Wrolstad, R. E. (1981). Color degradation in an ascorbic acidanthocyanin-flavanol model system. Journal of Food Science, 46(4), 1218-1236.

Rice-Evans, C. A., Miller, N. J., \& Paganga, G. (1996). Structure-antioxidant activity relationships of flavonoids and phenolic acids. Free Radical Biology and Medicine, 20(7), 933-956.

Roginsky, V., \& Alegria, A. E. (2005). Oxidation of tea extracts and tea catechins by molecular oxygen. Journal of Agricultural and Food Chemistry, 53(11) 4529-4535.

Roginsky, V., \& Barsukova, T. (2000). Kinetics of oxidation of hydroquinones by molecular oxygen. Effect of superoxide dismutase. Journal of the Chemical Society, Perkin Transactions, 2(7), 1575-1582.

Sang, S., Lapsley, K., Jeong, W.-S., Lachance, P. A., Ho, C.-T., \& Rosen, R. T. (2002) Antioxidative phenolic compounds isolated from almond skins (Prunus amygdalus batsch). Journal of Agricultural and Food Chemistry, 50(8), 2459-2463.

Shikov, V., Kammerer, D. R., Mihalev, K., Mollov, P., \& Carle, R. (2008). Heat stability of strawberry anthocyanins in model solutions containing natural copigments extracted from rose (Rosa damascena Mill.) petals. Journal of Agricultural and Food Chemistry, 56(18), 8521-8526.

Shikov, V., Kammerer, D. R., Mihalev, K., Mollov, P., \& Carle, R. (2012). Antioxidant capacity and colour stability of texture-improved canned strawberries as affected by the addition of rose (Rosa damascena Mill.) petal extracts. Food Research International, 46(2), 552-556.

da Silva, F. L., Escribano-Bailón, M. T., Pérez Alonso, J. J., Rivas-Gonzalo, J. C., \& Santos-Buelga, C. (2007). Anthocyanin pigments in strawberry. LWT - Food Science and Technology, 40(2), 374-382.

da Silva Pinto, M., Lajolo, F. M., \& Genovese, M. I. (2008). Bioactive compounds and quantification of total ellagic acid in strawberries (Fragaria $\mathrm{x}$ ananassa Duch.). Food Chemistry, 107(4), 1629-1635.

Singleton, V., \& Rossi, J. A. (1965). Colorimetry of total phenolics with phosphomolybdic-phosphotungstic acid reagents. American journal of Enology and Viticulture, 16(3), 144-158.

Solomon, O., Svanberg, U., \& Sahlström, A. (1995). Effect of oxygen and fluorescent light on the quality of orange juice during storage at $8^{\circ} \mathrm{C}$. Food Chemistry, 53(4), 363-368.

Sondheimer, E., \& Kertesz, Z. I. (1953). Participation of ascorbic acid in the destruction of anthocyanin in strawberry juice and model system. Journal of Food Science, 18(1-6), 475-479.

Tulyathan, V., Boulton, R. B., \& Singleton, V. L. (1989). Oxygen uptake by gallic acid as a model for similar reactions in wines. Journal of Agricultural and Food Chemistry, 37(4), 844-849.

Van De Velde, F., Tarola, A. M., Güemes, D., \& Pirovani, M. E. (2013). Bioactive compounds and antioxidant capacity of camarosa and selva strawberries (Fragaria $\times$ ananassa Duch.). Foods, 2(2), 120-131.

Zafrilla, P., Morillas, J., Mulero, J., Cayuela, J. M., Martínez-Cachá, A., Pardo, F., et al (2003). Changes during storage in conventional and ecological wine: phenolic content and antioxidant activity. Journal of Agricultural and Food Chemistry, 51(16), 4694-4700.

Zerdin, K., Rooney, M. L., \& Vermuë, J. (2003). The vitamin C content of orange juice packed in an oxygen scavenger material. Food Chemistry, 82(3), 387-395. 